\title{
BMJ Open Cohort profile: the Prospective Research In Stress-Related Military Operations (PRISMO) study in the Dutch Armed Forces
}

\author{
Sija J van der Wal, ${ }^{\oplus 1,2,3}$ Rosalie Gorter, ${ }^{\oplus 1,3}$ Alieke Reijnen, ${ }^{1,2,3}$ Elbert Geuze, ${ }^{1,3}$ \\ Eric Vermetten ${ }^{1,2,3,4}$
}

To cite: van der Wal SJ, Gorter R, Reijnen A, et al. Cohort profile: the Prospective Research In StressRelated Military Operations (PRISM0) study in the Dutch Armed Forces. BMJ Open 2019;9:e026670. doi:10.1136/ bmjopen-2018-026670

- Prepublication history for this paper is available online. To view these files, please visit the journal online (http://dx.doi. org/10.1136/bmjopen-2018026670).

Received 13 September 2018 Revised 18 December 2018 Accepted 19 December 2018

Check for updates

(c) Author(s) (or their employer(s)) 2019. Re-use permitted under CC BY-NC. No commercial re-use. See rights and permissions. Published by BMJ.

${ }^{1}$ Research Centre Military Mental Healthcare, Ministry of Defence, Utrecht, The Netherlands

${ }^{2}$ Department of Psychiatry, Leiden University Medical

Center, Leiden, The Netherlands

${ }^{3}$ Brain Center Rudolf Magnus,

Department of Psychiatry,

University Medical Center

Utrecht, Utrecht, The

Netherlands

${ }^{4}$ Arq Psychotrauma Expert Group, Diemen, The Netherlands

Correspondence to

Sija J van der Wal;

s.j.vanderwal@umcutrecht.nl

\section{ABSTRACT}

Purpose The Prospective Research in Stress-Related Military Operations (PRISMO) study was initiated to gain a better understanding of the long-term impact of military deployment on mental health, and to map the different biological and psychological factors that contribute to the development of stress-related mental health symptoms.

Participants The PRISMO cohort consists of a convenience sample of Dutch military personnel deployed to Afghanistan between 2005 and 2008. Baseline data collection resulted in the recruitment of 1032 military men and women. Combat troops as well as non-combat support troops were recruited to increase the representativeness of the sample to the population as a whole.

Findings to date The prevalence of various mental health symptoms increases after deployment in PRISM0 cohort members, but symptom progression over time appears to be specific for various mental health symptoms. For posttraumatic stress disorder, we found a short-term symptom increase within 6 months after deployment (8.2\%), and a long-term symptom increase at 5 years after deployment (12.9\%). Several biological vulnerability factors associated with the development of stress-related conditions after deployment were identified, including predeployment glucocorticoid receptor sensitivity and predeployment testosterone level. Thus far, 34 publications have resulted from the cohort.

Future plans Various analyses are planned that will include the prevalence of mental health symptoms at 10 years postdeployment, as well as trajectory analyses that capture the longitudinal development of symptoms. Furthermore, we will use a machine learning approach to develop predictive and network models for several mental health symptoms, incorporating biological, psychological and social factors.

\section{INTRODUCTION}

The Prospective Research In Stress-related Military Operations (PRISMO) study was initiated in 2005 by the Research Centre of the Military Mental Healthcare at the Dutch Ministry of Defence to prospectively and longitudinally study the biological underpinnings of the mental health of Dutch troops

\section{Strengths and limitations of this study}

- The Prospective Research in Stress-Related Military Operations study is the first to assess both biological and psychological measures in a large cohort of deployed military personnel using a prospective design, with measurements before and up to 10 years after deployment.

- Our study has detailed data on a variety of variables, especially on blood measures and psychological morbidity, which enables us to address many relevant research questions.

- Notable limitations of the study include the large reliance on self-report measures, the potential influence of non-response on our study findings and the lack of a non-deployed control group.

deployed to Afghanistan. At the time of the study's start, the long-term impact of deployment and exposure to traumatic events in wartime on mental health had already gained widespread recognition, as epidemiological evidence from a range of studies indicated that the incidence of mental health problems after deployment was quite substantial. ${ }^{1}$ However, both aetiological evidence as well as biological determinants were sparse, even though they were highly warranted. We therefore facilitated prospective research on the correlation between stress-related systems and the occurrence of mental health problems that were presented in deployed troops. Considering its size and estimated duration, the Dutch participation in the International Security Assistance Force (ISAF) in Afghanistan offered a unique opportunity to gain excellent understanding of the long-term impact of military deployment on mental health, and to map the different biological and psychological factors that contributed to the development of stress-related mental health symptoms. Whereas other cohort 
studies have attempted to address the impact of military service and deployment on mental health, the PRISMO study is different from other cohorts in including a predeployment measurement (cf. The King's Cohort ${ }^{2}$ ), collecting biological data in addition to psychological data (cf. The Millennium Cohort ${ }^{2}$, The Cooperative Studies Programme No. $566^{3}$ ), and including a longterm follow-up period up to 10 years after deployment (cf. The Army Study to Assess Risk \& Resilience in Service members - Pre/Post Deployment Study, ${ }^{4}$ Marine Resilience Study ${ }^{5}$ ). The findings generated by the PRISMO cohort can contribute to an outlook on vulnerability and resilience, while they are also aimed at aiding the identification of factors in order to protect the mental health of service personnel and veterans. The objective of the present paper is to provide a complete overview of the PRISMO cohort study and its most important findings to date.

\section{COHORT DESCRIPTION}

\section{Study participants, design and follow-up}

The PRISMO cohort aimed to recruit a convenience sample of 1000 military men and women who were deployed to Afghanistan between 2005 and 2008 as part of the ISAF, either as part of a Provincial Reconstruction Team or as part of Task Force Uruzgan. ISAF's most important objective was enabling the Afghan authorities to provide national security across national territory, and building the capacity of the Afghan National Security Forces. The sample size of the PRISMO cohort was based on a desired number of 50 post-traumatic stress disorder (PTSD) cases in the cohort and an anticipated 5\% prevalence of PTSD in the study population. Recruitment ran from March 2005 to May 2008 through oral presentations of the study at various army bases in the Netherlands. Both combat troops as well as non-combat support troops were recruited to increase the representativeness of the sample to the population as a whole. A financial compensation was offered in exchange for participation. After reading the study information, a total of 1032 potential participants signed up for participation prior to deployment and provided written informed consent. A total of 1007 study participants were deployed for about 4 months. The total sample represents approximately $4 \%$ of those deployed to Afghanistan as part of the Dutch contribution to ISAF. PRISMO cohort demographics and other characteristics are described in table 1. Complete information on demographics is not available for the full cohort of Dutch ISAF veterans. Therefore we cannot be sure of the representativeness of the sample. The study was approved by the Institutional Review Board of the University Medical Centre Utrecht (Utrecht, The Netherlands).

Up to now, PRISMO has had six completed rounds of measurements spread out over 5 years (figure 1). The seventh round of measurements (10-year follow-up) is currently carried out and planned to be completed in 2019. The baseline measurement $\left(T_{0}\right)$ was carried
Table 1 Predeployment characteristics of the Prospective Research in Stress-Related Military Operations cohort $(n=1007)$

\begin{tabular}{|c|c|c|}
\hline Variable & $\mathbf{N}$ & $\%$ \\
\hline \multicolumn{3}{|l|}{ Gender } \\
\hline Male & 921 & 91.5 \\
\hline Female & 86 & 8.5 \\
\hline \multicolumn{3}{|l|}{ Age $(\text { years })^{\star}$} \\
\hline$<21$ & 139 & 13.9 \\
\hline $21-24$ & 327 & 32.7 \\
\hline $25-29$ & 201 & 20.1 \\
\hline $30-34$ & 118 & 11.8 \\
\hline 35-39 & 68 & 6.8 \\
\hline $40-44$ & 64 & 6.4 \\
\hline$\geq 45$ & 83 & 8.3 \\
\hline \multicolumn{3}{|l|}{ Education level ${ }^{*} \dagger$} \\
\hline Low & 366 & 40.0 \\
\hline Moderate & 442 & 48.4 \\
\hline High & 102 & 11.2 \\
\hline \multicolumn{3}{|l|}{ Relationship* } \\
\hline Yes & 552 & 61.6 \\
\hline No & 344 & 38.4 \\
\hline \multicolumn{3}{|l|}{ Rank $^{*}$} \\
\hline Private & 394 & 40.2 \\
\hline Corporal & 203 & 20.7 \\
\hline Non-commissioned officer & 251 & 25.6 \\
\hline Staff officer & 132 & 13.5 \\
\hline \multicolumn{3}{|l|}{ Previous deployments* } \\
\hline 0 & 479 & 53.3 \\
\hline 1 & 229 & 25.5 \\
\hline 2 & 104 & 11.6 \\
\hline$\geq 3$ & 87 & 9.7 \\
\hline
\end{tabular}

*Sample sizes might not add up to total participants due to missing data in the descriptive values.

†Education (International Standard Classification of Education levels): Low=primary and lower secondary education;

Moderate=upper secondary, postsecondary non-tertiary and short cycle tertiary education; High=bachelor, master and doctoral education.

out approximately 1 month before deployment and completed at the army base. Collection of blood samples was performed between 07:00 and 09:00 at the base.

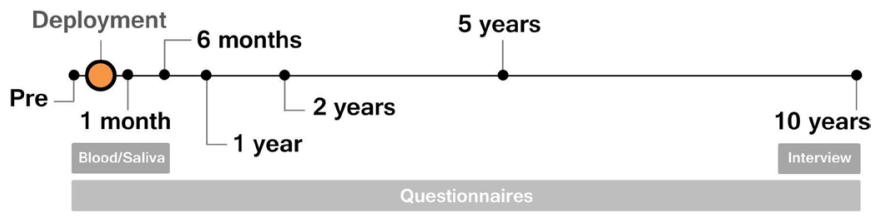

Figure 1 Design of the Prospective Research in StressRelated Military Operations study. 
Participation also included collection of saliva samples on two consecutive days, with participants sending in their batches by mail. The first two follow-up assessments were also completed at the army base, at approximately 1 month $\left(\mathrm{T}_{1}\right)$ and 6 months $\left(\mathrm{T}_{2}\right)$ after the soldiers returned home. The 1-year $\left(\mathrm{T}_{3}\right)$, 2-year $\left(\mathrm{T}_{4}\right)$ and 5-year $\left(\mathrm{T}_{5}\right)$ assessments were completed at home. Questionnaires were sent in by mail $\left(\mathrm{T}_{3}\right.$ and $\left.\mathrm{T}_{4}\right)$ or were completed online $\left(\mathrm{T}_{5}\right)$. Currently, the 10-year follow-up $\left(\mathrm{T}_{6}\right)$ is conducted at the Research Centre of the Military Mental Healthcare. Participants are invited for a face-to-face interview and for filling in questionnaires. Those participants who do not wish to partake in an interview are asked to fill out questionnaires at home. Psychiatric diagnoses derived from the structural clinical interview are lacking for this group.

In order to minimise dropout in the follow-up assessments, all participants were repeatedly contacted (up to five times) through email, mail and/or telephone, in order to remind them to complete the questionnaires. Still, response rates dropped (figure 2), and at the fifth follow-up measurement (5-year postdeployment), a total of 581 respondents of the original sample were retained. Detailed information on attrition can be found in table 2 , where information on differences in demographic

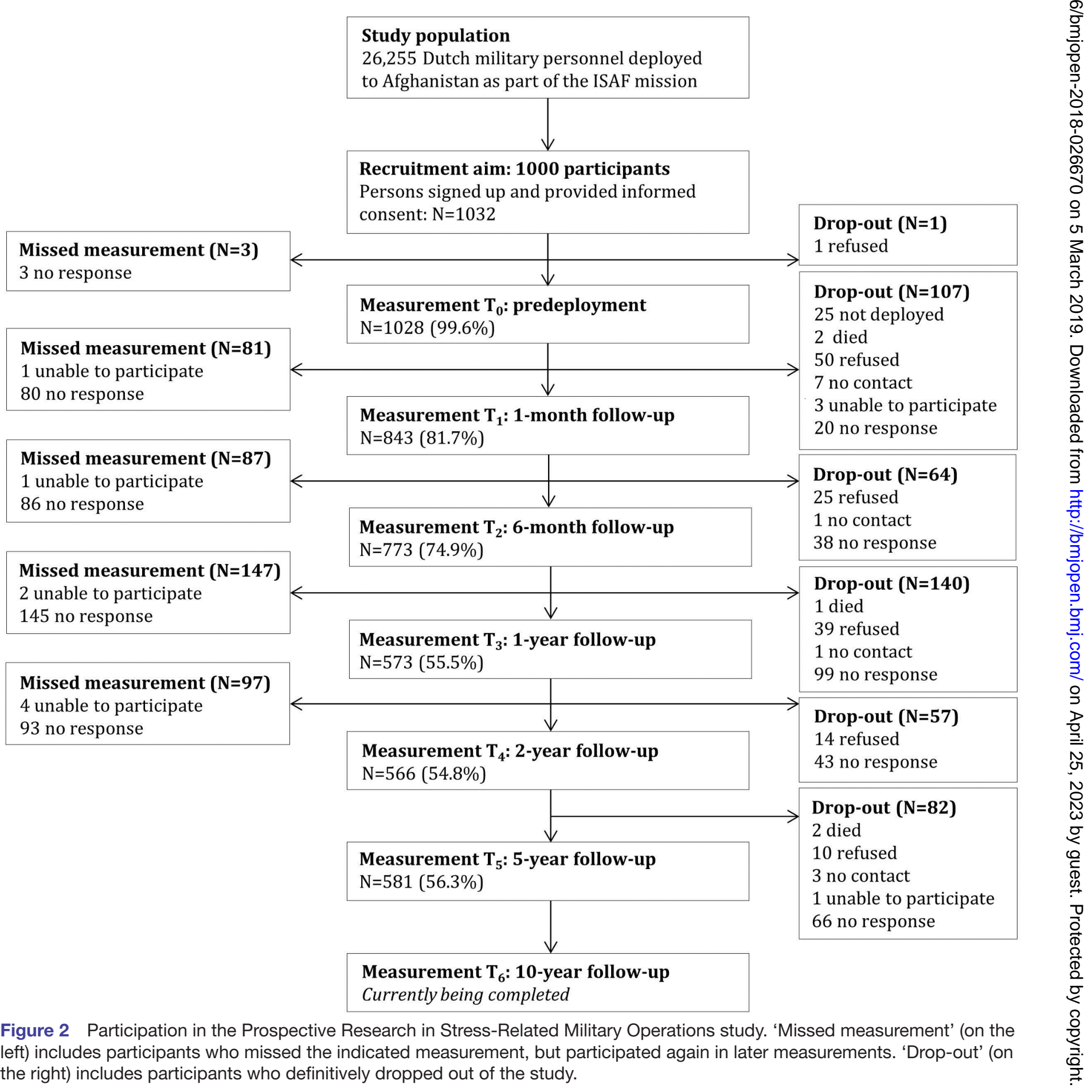


Table 2 Results of the drop-out analysis of several demographic characteristics

\begin{tabular}{|c|c|c|c|}
\hline & $\begin{array}{l}\text { Participants remaining in the cohort } \\
\text { until } 5 \text {-year follow-up }(n=581)^{*} \\
\text { count }(\%)\end{array}$ & $\begin{array}{l}\text { Participants lost to follow-up } \\
\text { until } 5 \text {-year follow-up }(n=451)^{\star} \\
\text { count }(\%)\end{array}$ & $P$ value \\
\hline Gender & $(n=581)$ & $(n=451)$ & \\
\hline Male & $527(90.7 \%)$ & $412(91.4 \%)$ & 0.719 \\
\hline Female & $54(9.3 \%)$ & $39(8.6 \%)$ & \\
\hline Age & $(n=580)$ & $(n=445)$ & \\
\hline Mean (SD) & $30.7(9.50)$ & $25.4(6.95)$ & $<0.001$ \\
\hline Education level† & $(n=542)$ & $(n=390)$ & \\
\hline Low & $173(31.9 \%)$ & $202(51.8 \%)$ & $<0.001$ \\
\hline Moderate & $284(52.4 \%)$ & $168(43.1 \%)$ & \\
\hline High & $85(15.7 \%)$ & $20(5.1 \%)$ & \\
\hline Relationship & $(n=539)$ & $(n=379)$ & \\
\hline Yes & $181(33.6 \%)$ & $169(44.6 \%)$ & 0.001 \\
\hline No & $358(66.4 \%)$ & $210(55.4 \%)$ & \\
\hline Rank & $(n=578)$ & $(n=424)$ & \\
\hline Private & $169(29.2 \%)$ & $232(54.7 \%)$ & $<0.001$ \\
\hline Corporal & $113(19.6 \%)$ & $94(22.2 \%)$ & \\
\hline Non-commissioned officer & $191(33.0 \%)$ & $68(16 \%)$ & \\
\hline Staff officer & $105(18.2 \%)$ & $30(7.1 \%)$ & \\
\hline Previous deployment & $(n=531)$ & $(n=389)$ & \\
\hline 0 & $246(46.3 \%)$ & $245(63.0 \%)$ & $<0.001$ \\
\hline 1 & $140(26.4 \%)$ & 95 (24.4\%) & \\
\hline$\geq 2$ & $145(27.3 \%)$ & 49 (12.6\%) & \\
\hline Function during deployment & $(n=474)$ & $(n=344)$ & \\
\hline Inside & $187(39.5 \%)$ & $68(19.8 \%)$ & $<0.001$ \\
\hline Outside & $244(51.5 \%)$ & $246(71.5 \%)$ & \\
\hline Both & $43(9.1 \%)$ & $30(8.7 \%)$ & \\
\hline Deployment year & $(n=581)$ & $(n=451)$ & \\
\hline $2005 / 2006$ & $152(26.2 \%)$ & $112(24.8 \%)$ & 0.628 \\
\hline $2007 / 2008$ & 429 (73.8\%) & 339 (75.2\%) & \\
\hline
\end{tabular}

*Sample sizes might not add up to total participants due to missing data in the descriptive values;

†Education (International Standard Classification of Education levels): Low=primary and lower secondary education; Moderate=upper secondary, postsecondary non-tertiary and short cycle tertiary education; High=bachelor, master and doctoral education; Differences on descriptive characteristics between those remaining in the cohort and those lost to follow-up were tested with a t-test (continuous) or $\chi^{2}$-test (categorical).

characteristics between those remaining in the cohort at the 5-year assessment and those lost to follow-up is presented. Prior to deployment, dropouts were significantly younger, had a lower education level, were more likely to be in a relationship, had a lower rank during deployment and had less often been deployed prior to this deployment. Dropouts also more often had a function outside the military base during their deployment in comparison to participants that remained in the cohort.

\section{Study measures}

The PRISMO study contains a wide variety of measures that are listed in table 3. All data were collected via blood samples, saliva samples, validated questionnaires and interviews. The data include the biological and psychological measures that we considered to be relevant for mental health in a military population, with special focus on stress-related mental health symptoms. Biological parameters in the field of stress regulatory systems-and related neuroendocrine and immunology systems—were determined during expert meetings at the time of study set-up. It must be noted that, since the moment of the study's design, the field of (epi)genetics has developed with much potential for prospective studies. The biological PRISMO samples have therefore been used for 
Table 3 Main study measures in the Prospective Research in Stress-Related Military Operations study over time

\begin{tabular}{|c|c|c|c|c|c|c|c|}
\hline & $\begin{array}{l}T_{0}: \\
\text { Predeployment }\end{array}$ & $\begin{array}{l}T_{1}: \text { 1-month } \\
\text { follow-up }\end{array}$ & $\begin{array}{l}T_{2}: 6 \text {-month } \\
\text { follow-up }\end{array}$ & $\begin{array}{l}T_{3}: \text { 1-year } \\
\text { follow-up }\end{array}$ & $\begin{array}{l}T_{4}: \text { 2-year } \\
\text { follow-up }\end{array}$ & $\begin{array}{l}T_{5}: 5 \text {-year } \\
\text { follow-up }\end{array}$ & $\begin{array}{l}T_{6}: 10 \text {-year } \\
\text { follow-up }\end{array}$ \\
\hline \multicolumn{8}{|l|}{ (Epi) Genetics } \\
\hline Telomere length & Plasma & Plasma & Plasma & & & & \\
\hline DNA methylation & Plasma & Plasma & Plasma & & & & \\
\hline GR and FKBP5 SNPs & Plasma & Plasma & Plasma & & & & \\
\hline $\begin{array}{l}\text { mRNA expression } \\
\text { PBMCs }\end{array}$ & Plasma & Plasma & Plasma & & & & \\
\hline \multicolumn{8}{|l|}{ Immunology } \\
\hline $\begin{array}{l}\text { Leucocyte } \\
\text { subpopulations }\end{array}$ & Plasma & Plasma & Plasma & & & & \\
\hline T-cell cytokine secretion & Plasma & Plasma & Plasma & & & & \\
\hline $\begin{array}{l}\text { PBMC glucocorticoid } \\
\text { binding }\end{array}$ & Plasma & Plasma & Plasma & & & & \\
\hline PBMC IL-1 $\beta$ reactivity & Plasma & Plasma & Plasma & & & & \\
\hline \multicolumn{8}{|l|}{ Neuroendocrinology } \\
\hline Testosterone & Plasma & Plasma & Plasma & & & & \\
\hline Cortisol & Plasma, salivary & $\begin{array}{l}\text { Plasma, } \\
\text { salivary }\end{array}$ & $\begin{array}{l}\text { Plasma, } \\
\text { salivary }\end{array}$ & & & & \\
\hline SHBG & Plasma & Plasma & Plasma & & & & \\
\hline Oxytocin & Plasma & Plasma & Plasma & & & & \\
\hline Vasopressin & Plasma & Plasma & Plasma & & & & \\
\hline Neuropeptide Y & Plasma & Plasma & Plasma & & & & \\
\hline GABA & Plasma & Plasma & Plasma & & & & \\
\hline Demographic factors & Self-report & Self-report & Self-report & Self-report & Self-report & Self-report & $\begin{array}{l}\text { Self-report, } \\
\text { interview }\end{array}$ \\
\hline
\end{tabular}

General health and

psychological morbidity

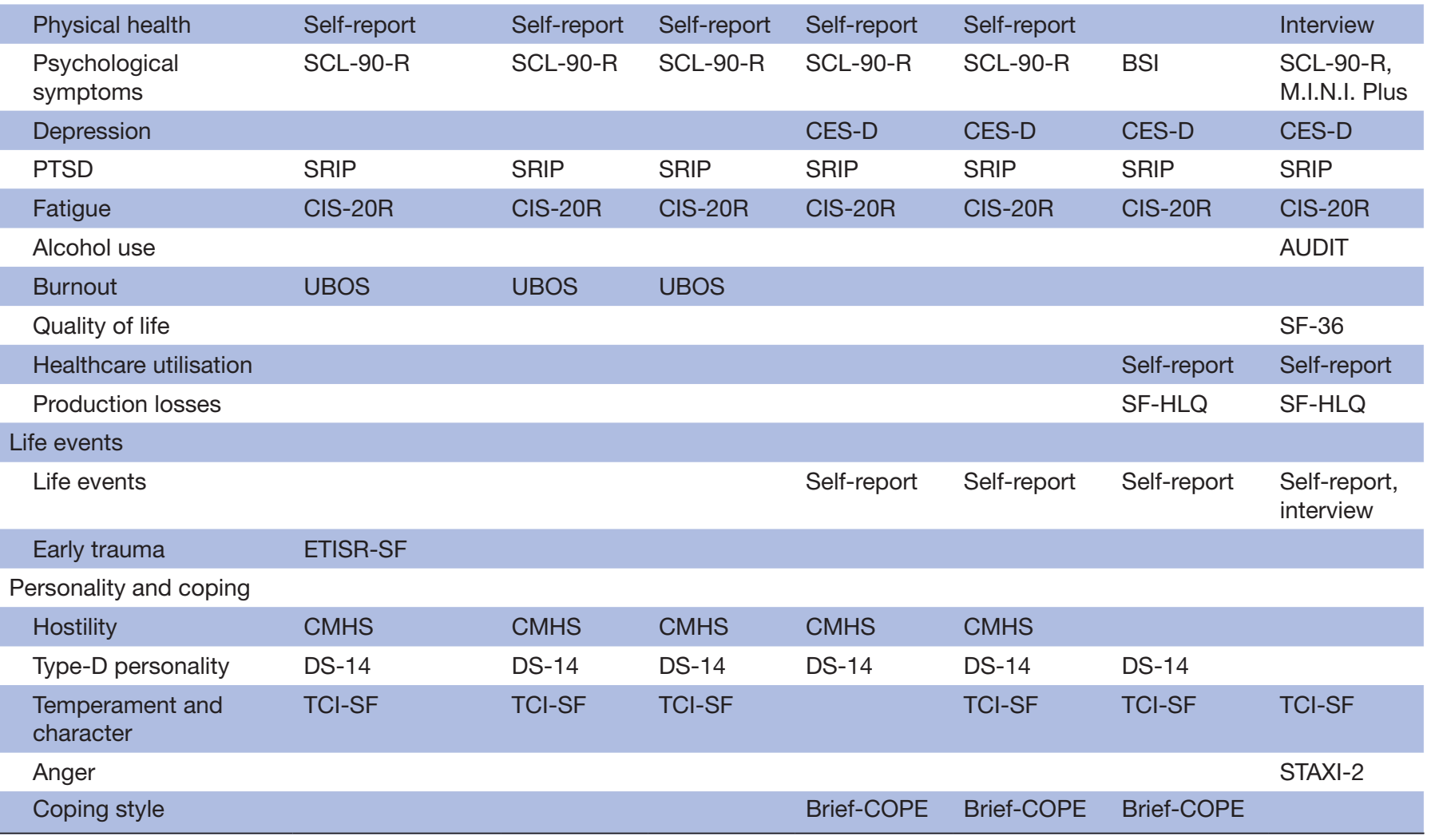


Table 3 Continued

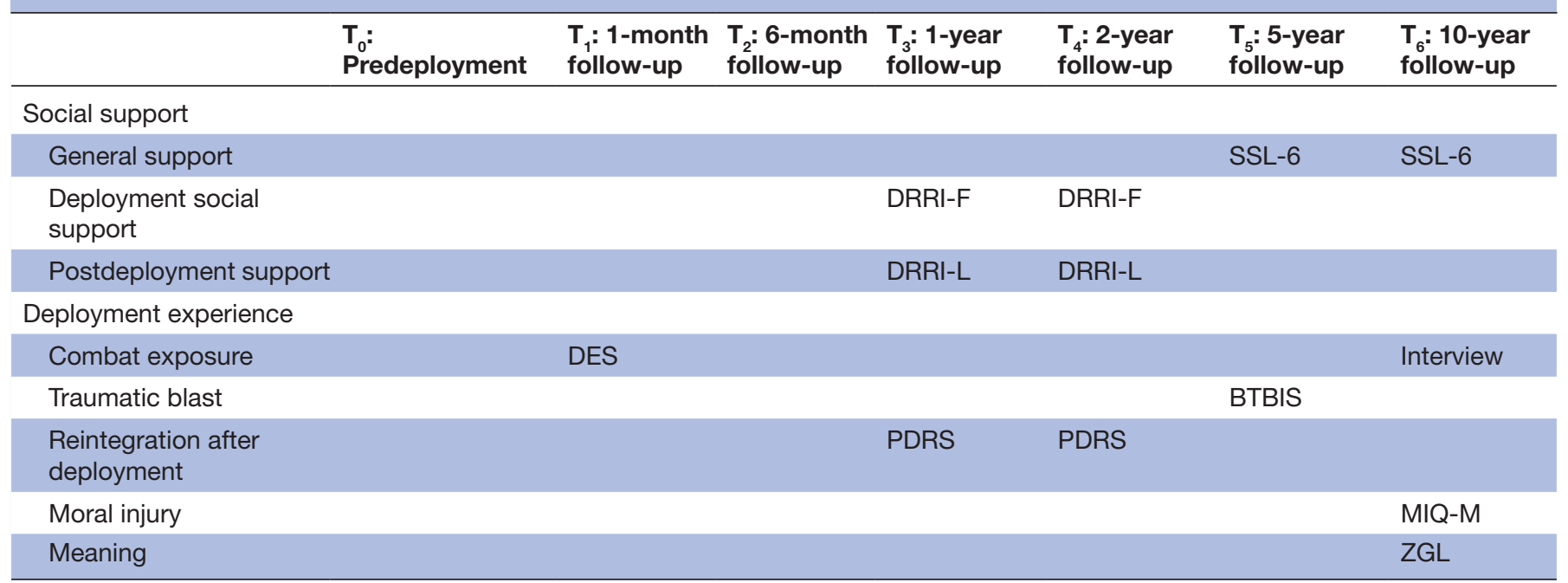

AUDIT, Alcohol Use Disorders Identification Test ${ }^{3031}$; Brief-COPE, Brief COPE Inventory ${ }^{32}$; BSI, Brief Symptom Inventory ${ }^{43}$; BTBIS, Brief Traumatic Brain Injury Screen ${ }^{34-36}$; CES-D, Centre for Epidemiologic Studies Depression Scale ${ }^{37}$; CIS-20R, Checklist Individual Strength ${ }^{1038}$; CMHS, Cook-Medley Hostility Scale ${ }^{39} 40$; DES, Deployment Experience Scale $e^{24}$; DRRI, Deployment Risk and Resilience Inventory ${ }^{41}$; DS-14, Type-D Scale ${ }^{42}$; ETISR-SF, Early Trauma Inventory-Self Report ${ }^{43}$; GR, Glucocorticoid receptor; M.I.N.I. Plus, MINI-International Neuropsychiatric Interview-Plus ${ }^{11}$; MIQ-M, Moral Injury Questionnaire-Military version ${ }^{44}$; PBMC, Peripheral blood mononuclear cells; PDRS, PostDeployment Reintegration Scale ${ }^{45}$; SCL-90-R, Symptom CheckList ${ }^{86}{ }^{47}$; SF-36, Medical Outcome Study Short-Form Survey ${ }^{48} 49$; SF-HLQ, Short Form-Health and Labour Questionnaire ${ }^{5051}$; SHBG, Sex hormone-binding globulin; SNP, Single nucleotide polymorphism; SRIP, Self-Rating Inventory for PTSD ${ }^{67}$; SSL-6, Social Support List ${ }^{52}$ 53; STAXI-2, State-Trait Anger Expression Inventory- $2^{5455}$; TCI-SF, Temperament and Character Inventory-Short Form ${ }^{567}$; UBOS, Utrecht Burnout Scale ${ }^{58} 59$; ZGL, Zingevingslijst. ${ }^{60}$

research opportunities that became known later on in the study.

\section{Outcomes}

The primary outcome in PRISMO is psychological morbidity, which was measured with several validated questionnaires. Symptoms of PTSD were measured with the Dutch Self-Rating Inventory for PTSD (SRIP), ${ }^{6}$ a questionnaire with good internal consistency, discriminant validity and concurrent validity with other PTSD measures. ${ }^{67}$ Throughout the study, other mental health problems were assessed using the depression, anxiety, somatic symptoms and hostility subscales of the Dutch revised Symptom Checklist (SCL-90-R) ${ }^{8}$ or the Dutch Brief Symptom Inventory (BSI), ${ }^{9}$ while fatigue was measured using the Checklist Individual Strength (CIS-20R). ${ }^{10}$

\section{Covariates}

A wide range of covariates has been measured in PRISMO. Biological covariates included several (epi) genetic measures (eg, telomere length, DNA methylation), immunological measures (eg, cytokine secretion, glucocorticoid binding) and neuroendocrinological measures (eg, hormone levels). Psychological covariates included demographic factors, deployment experience, important life events (eg, serious illness, death of a significant other, break up, marriage, financial problems), early trauma, personality, coping style and social support. A full list of the used questionnaires and information on the validity of the instruments can be found in table 3 and the cited references.

\section{Cohort subsamples}

In 2011, PRISMO started an additional measurement on a subsample of the cohort, PRISMO+. The aim of this substudy was to validate self-reported symptoms on questionnaires by means of comparison to reported symptoms in a structured clinical interview and anamnesis (ie, the participant's medical history as by their own recollection). The sample was based on random sampling in four subgroups of PRISMO participants: participants with substantial PTSD symptoms, participants with substantial depressive mood symptoms, participants with substantial fatigue symptoms and participants without symptoms on previous completed questionnaires. In total, 141 participants completed the additional assessment consisting of the M.I.N.I. International Neuropsychiatric Interview Plus, ${ }^{11}$ the Clinician Administered PTSD Scale, ${ }^{12}$ an anamnesis, and the self-report measures BSI, ${ }^{9}$ SRIP $^{6}$ and CIS-20R ${ }^{10}$ Furthermore, a second related substudy was set up: PRISMO SCAN. ${ }^{13-15}$ This study was performed in a small subsample $(n=33)$ of the initial cohort supplemented with a control group of soldiers who were never deployed. It is composed of functional MRI (fMRI) scanning, both prior to deployment and twice after return home. The aim of this study was investigating the effects of severe stress on neural functioning, together with the factors that mediate individual differences in the neural sequelae of stress. ${ }^{13}$ 


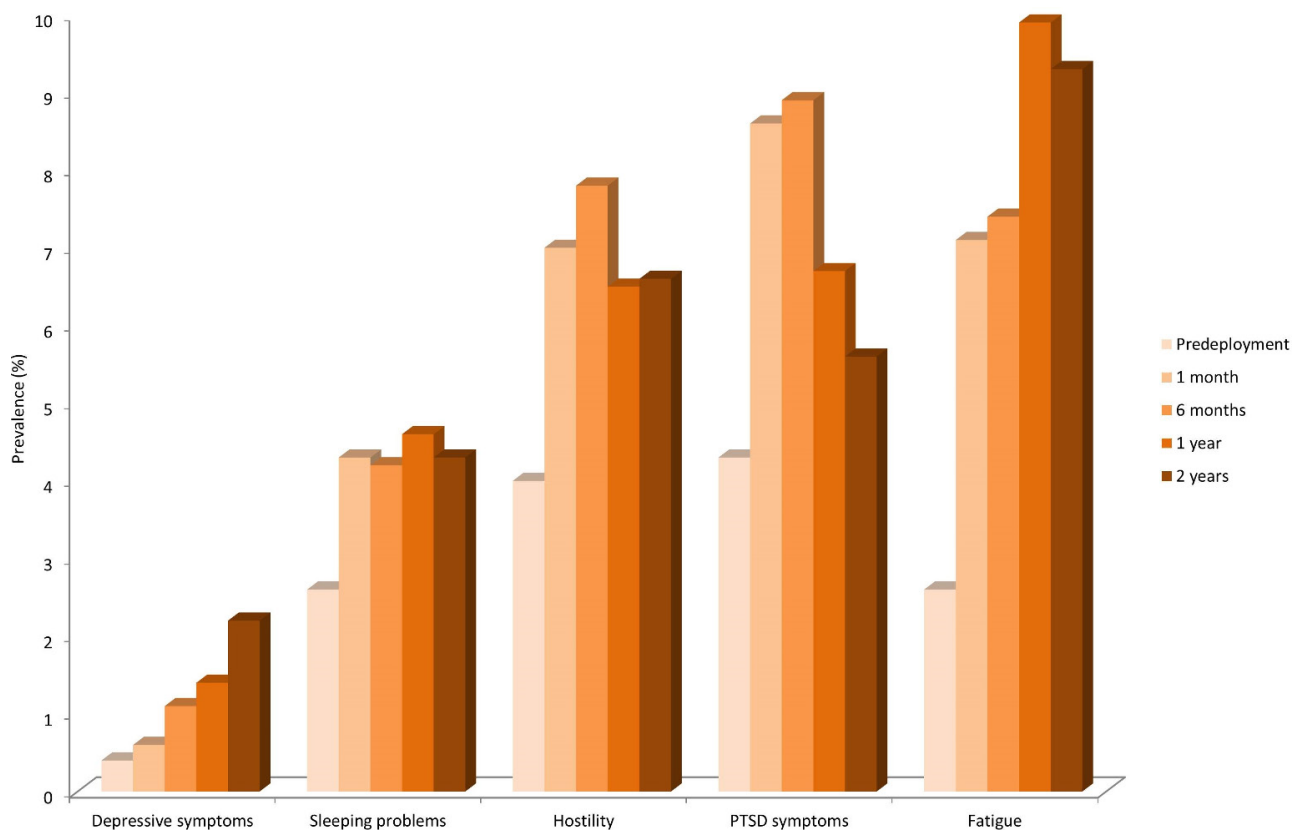

Figure 3 Prevalence of mental health symptoms in the Prospective Research in Stress-Related Military Operations cohort. Prevalence rates for all questionnaires were estimated based on 95th percentile scores as reported in the respective manuals or source publications. Changes in all prevalence rates from baseline to 1 month postdeployment were significant.

\section{Patient and public involvement}

The PRISMO cohort is set up in response to the increased demand for knowledge about prevalence rates and aetiology of stress-related conditions after deployment. Although we always kept the interest of veterans' mental health in mind, veterans were not involved in the design, recruitment or conduct of the study. Results of the study are disseminated to study participants by the studies website, newsletters, public summaries and individual feedback during the final follow-up measurement.

\section{FINDINGS TO DATE}

Research with PRISMO data covers a wide range of topics and methods for data analysis. In this section, we summarise the key findings on the most important research themes that the PRISMO cohort has contributed to. To date, a total of 34 publications have resulted from the cohort. A complete list of publications can be found online (www.prismo.nl).

The identification of single biological vulnerability factors associated with the development of stress-related conditions after deployment is one of the most important topics within PRISMO. We first focused on the glucocorticoid receptor (GR) and found that, relative to matched comparison subjects, the predeployment GR number in peripheral blood mononuclear cells was significantly higher in participants who developed a high level of PTSD symptoms postdeployment. ${ }^{16}$ This difference in glucocorticoid sensitivity persisted until at least 6 months after the return from deployment. ${ }^{17}$ The sensitivity of the GR also appeared to play a role in the development of depressive or fatigue symptoms postdeployment. ${ }^{1718}$
More recently, several peripherally measured neuroendocrine factors as potential biomarkers were studied. It was shown that a lower predeployment testosterone level was predictive for the development of PTSD symptoms at 1 and 2 years after deployment. ${ }^{19}$ Levels of neuropeptide $\mathrm{Y}$, oxytocine and arginine vasopressin were not found to be related to the level of reported PTSD symptoms over time. ${ }^{20}{ }^{21}$ In the genetic chapter of the PRISMO study it was shown that postdeployment longitudinal decreases in methylation of the SKA2 gene, a gene involved in GR transactivation, were associated with the development of PTSD symptoms after return. ${ }^{22}$ In addition, our genome-wide blood DNA methylation analysis identified three other novel genomic regions where longitudinal decreases in DNA methylation mark PTSD susceptibility. ${ }^{23}$

Another important part of the research using PRISMO data has concerned the prevalence and developmental trajectories of various mental health problems in the years after deployment. It showed that the prevalence of various mental health symptoms increases after deployment, but symptom progression over time appears to be specific for various mental health symptoms (figure 3). ${ }^{24}$ To assess PTSD symptom development in more detail, PTSD symptoms were longitudinally assessed up to 5 years after deployment. Besides a short-term symptom increase within the first 6 months after deployment (8.2\% above cut-off on a self-report PTSD questionnaire), we found a long-term symptom increase at 5 years after deployment (12.9\% above cut-off) ${ }^{25}$ Furthermore, three developmental trajectories were identified using a latent growth mixture model (figure 4): a low stable trajectory of PTSD symptoms (resilient; 85.2\%), a trajectory showing a moderate level of symptoms that increased 


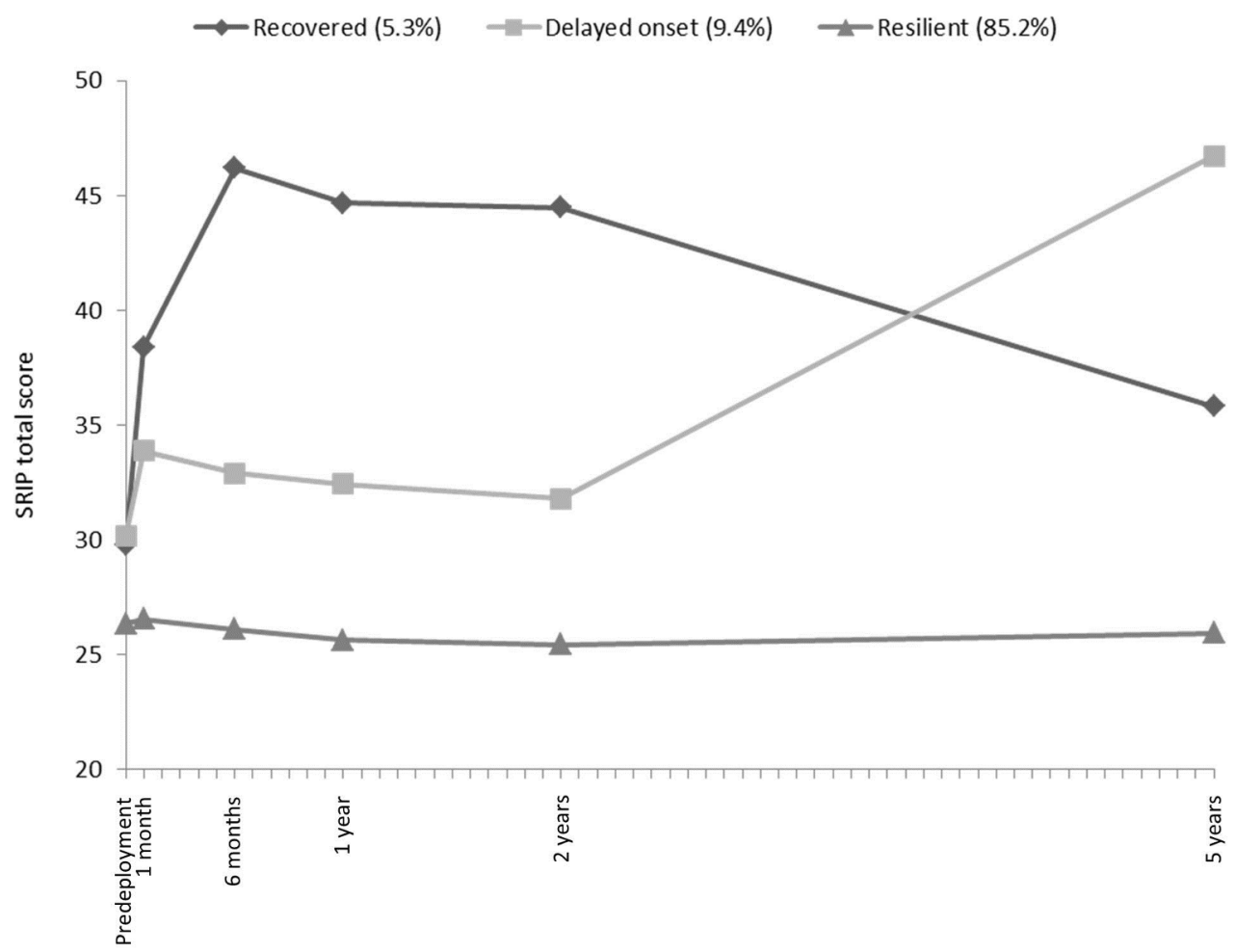

Figure 4 Latent developmental trajectories of post-traumatic stress symptoms in the Prospective Research in Stress-Related Military Operations cohort $(\mathrm{n}=960)$. SRIP, Self-Rating Inventory for Post-traumatic Stress Disorder.

strongly after 2years postdeployment (delayed onset; $9.4 \%$ ) and a trajectory with initially increasing symptoms that decreased after the first year postdeployment (recovered; $5.3 \%) .{ }^{25}$

\section{STRENGTHS AND LIMITATIONS}

PRISMO is unique in being the first study to assess both biological and psychological measures in a large cohort of deployed military personnel using a prospective longitudinal design, with measurements before and up to 10 years after deployment. This design enabled a differentiation of a range of vulnerability factors for the onset and course of stress-related mental health problems. However, the large size and complexity of the cohort necessitates a discussion on some important limitations.

PRISMO largely relies on self-report measures and is therefore subject to the inherent biases associated with studies of this kind. Although standardised and validated screening instruments were used to measure the prevalence of mental health problems, it might have resulted in higher prevalence estimates compared with clinician diagnoses. ${ }^{2627}$ This potential source of bias can be assessed using the diagnoses derived from the clinical interview in the 10-year follow-up, which is currently being conducted. On the other hand, mental health symptoms may be under-reported given the stigma attached to mental disorders, especially within military populations. ${ }^{28}{ }^{29}$ Although attrition is inevitable in longitudinal cohort studies, it is obviously a concern. We were able to maintain approximately $55 \%$ of the original sample for the 1-, 2- and 5-year assessment. As we have showed before, dropouts differed significantly on several baseline characteristics from the respondents who remained in the cohort. Influence of non-response on the study findings can therefore not be ruled out and might limit generalizability. However, the effects of this limitation can be reduced by use of statistical imputation techniques. Finally, there is no non-deployed control group included in this study, and the effects found therefore cannot be solely attributed to deployment. The inclusion of such a control group in future research would therefore be recommended.

\section{COLLABORATION}

Opportunities for external investigators to share data are limited, partly due to the military nature of the cohort. Further information can be obtained from the Research Centre of the Military Mental Healthcare through Joke Geluk (jwc.geluk@mindef.nl).

Acknowledgements The authors thank the Dutch commanders and troops and all members of the PRISMO team involved in data acquisition for their ongoing commitment to the study.

Contributors Study concept and design: EV, EG; acquisition of data: EV, EG, AR, SJvdW; drafting of the manuscript: SJvdW; data analyses and putting together tables and figures: RG, SJvdW; critical revision of the manuscript on intellectual content: EV, EG, RG, AR, SJvdW. All authors have read and approved the final version.

Funding The PRISM0 study is financially supported by the Dutch Ministry of Defence.

Competing interests None declared.

Patient consent for publication Not required. 
Ethics approval Approval was obtained from the ethical committee of the University Medical Center Utrecht.

Provenance and peer review Not commissioned; externally peer reviewed.

Data sharing statement The PRISM0 team is open to potential research collaborations with other scientists, with the proviso that data sharing is limited due to the military nature of the cohort. Researchers interested in collaboration should contact the Research Centre of the Military Mental Healthcare at jwc.geluk@ mindef.nl with their expression of interest.

Open access This is an open access article distributed in accordance with the Creative Commons Attribution Non Commercial (CC BY-NC 4.0) license, which permits others to distribute, remix, adapt, build upon this work non-commercially, and license their derivative works on different terms, provided the original work is properly cited, appropriate credit is given, any changes made indicated, and the use is non-commercial. See: http://creativecommons.org/licenses/by-nc/4.0/.

\section{REFERENCES}

1. Stimpson NJ, Thomas HV, Weightman AL, et al. Psychiatric disorder in veterans of the Persian Gulf War of 1991. Br J Psychiatry 2003;182:391-403

2. Pinder RJ, Greenberg N, Boyko EJ, et al. Profile of two cohorts: UK and US prospective studies of military health. Int $J$ Epidemiol 2012;41:1272-82.

3. Vasterling JJ, Aslan M, Proctor SP, et al. Longitudinal examination of posttraumatic stress disorder as a long-term outcome of Iraq War Deployment. Am J Epidemiol 2016;184:796-805.

4. Ursano RJ, Colpe LJ, Heeringa SG, et al. The Army study to assess risk and resilience in servicemembers (Army STARRS). Psychiatry 2014;77:107-19.

5. Baker DG, Nash WP, Litz BT, et al. Predictors of risk and resilience for posttraumatic stress disorder among ground combat Marines: methods of the Marine Resiliency Study. Prev Chronic Dis 2012;9:E97.

6. Hovens JE, van der Ploeg HM, Bramsen I, et al. The development of the Self-Rating Inventory for Posttraumatic Stress Disorder. Acta Psychiatr Scand 1994;90:172-83.

7. Hovens JE, Bramsen I, van der Ploeg HM. Self-rating inventory for posttraumatic stress disorder: review of the psychometric properties of a new brief Dutch screening instrument. Percept Mot Skills 2002;94:996-1008.

8. Derogatis LR. SCL-90-R. Administration, scoring and procedures manual. 3rd ed. Minnaepolis, MN: National Computer Systems, 1994.

9. Derogatis LR. Brief Symptom Inventory (BSI): Administration, scoring, and procedures manual. Minneapolis, MN: National Computer Systems, 1993

10. Vercoulen JH, Swanink CM, Fennis JF, et al. Dimensional assessment of chronic fatigue syndrome. J Psychosom Res 1994;38:383-92.

11. Sheehan DV, Lecrubier Y, Sheehan KH, et al. The Mini-International Neuropsychiatric Interview (M.I.N.I.): the development and validation of a structured diagnostic psychiatric interview for DSM-IV and ICD10. J Clin Psychiatry 1998;59:22-33.

12. Blake DD, Weathers FW, Nagy LM, et al. The development of a clinician-administered PTSD scale. J Trauma Stress 1995;8:75-90.

13. van Wingen GA, Geuze E, Vermetten $\mathrm{E}$, et al. Perceived threat predicts the neural sequelae of combat stress. Mol Psychiatry 2011;16:664-71.

14. van Wingen GA, Geuze E, Caan MW, et al. Persistent and reversible consequences of combat stress on the mesofrontal circuit and cognition. Proc Natl Acad Sci U S A 2012;109:15508-13.

15. Geuze $\mathrm{E}$, van Wingen GA, van Zuiden $\mathrm{M}$, et al. Glucocorticoid receptor number predicts increase in amygdala activity after severe stress. Psychoneuroendocrinology 2012;37:1837-44.

16. van Zuiden M, Geuze E, Willemen HL, et al. Pre-existing high glucocorticoid receptor number predicting development of posttraumatic stress symptoms after military deployment. Am J Psychiatry 2011;168:89-96.

17. van Zuiden M, Kavelaars A, Vermetten E, et al. Pre-deployment differences in glucocorticoid sensitivity of leukocytes in soldiers developing symptoms of PTSD, depression or fatigue persist after return from military deployment. Psychoneuroendocrinology 2015;51:513-24.

18. van Zuiden M, Heijnen CJ, Maas M, et al. Glucocorticoid sensitivity of leukocytes predicts PTSD, depressive and fatigue symptoms after military deployment: A prospective study. Psychoneuroendocrinology 2012;37:1822-36.

19. Reijnen A, Geuze E, Vermetten E. The effect of deployment to a combat zone on testosterone levels and the association with the development of posttraumatic stress symptoms: a longitudinal prospective Dutch military cohort study. Psychoneuroendocrinology 2015;51:525-33.

20. Reijnen A, Geuze E, Vermetten E. Individual variation in plasma oxytocin and vasopressin levels in relation to the development of combat-related PTSD in a large military cohort. J Psychiatr Res 2017;94:88-95.

21. Reijnen A, Geuze E, Eekhout I, et al. Biological profiling of plasma neuropeptide $Y$ in relation to posttraumatic stress symptoms in two combat cohorts. Biol Psychol 2018;134:72-9.

22. Boks MP, Rutten BP, Geuze E, et al. SKA2 Methylation is Involved in Cortisol Stress Reactivity and Predicts the Development of Post-Traumatic Stress Disorder (PTSD) After Military Deployment Neuropsychopharmacology 2016;41:1350-6.

23. Rutten BPF, Vermetten $\mathrm{E}$, Vinkers $\mathrm{CH}$, et al. Longitudinal analyses of the DNA methylome in deployed military servicemen identify susceptibility loci for post-traumatic stress disorder. Mol Psychiatry 2018;23:1145-56.

24. Reijnen A, Rademaker AR, Vermetten E, et al. Prevalence of mental health symptoms in Dutch military personnel returning from deployment to Afghanistan: a 2-year longitudinal analysis. Eur Psychiatry 2015;30:341-6.

25. Eekhout I, Reijnen A, Vermetten E, et al. Post-traumatic stress symptoms 5 years after military deployment to Afghanistan: an observational cohort study. Lancet Psychiatry 2016;3:58-64.

26. Engelhard IM, van den Hout MA, Weerts J, et al. Deployment-related stress and trauma in Dutch soldiers returning from Iraq. Prospective study. Br J Psychiatry 2007;191:140-5.

27. Frueh BC, Hamner MB, Cahill SP, et al. Apparent symptom overreporting in combat veterans evaluated for PTSD. Clin Psychol Rev 2000;20:853-85.

28. Warner $\mathrm{CH}$, Appenzeller GN, Grieger T, et al. Importance of anonymity to encourage honest reporting in mental health screening after combat deployment. Arch Gen Psychiatry 2011;68:1065-71.

29. Hoge CW, Castro CA, Messer SC, et al. Combat duty in Iraq and Afghanistan, mental health problems, and barriers to care. $N$ Engl $J$ Med 2004;351:13-22.

30. Babor TF, Biddle-Higgins JC, Saunders JB, et al. AUDIT: The Alcohol Use Disorders Identification Test: Guidelines for use in primary health care. Geneva, Switzerland: World Health Organization, 2001.

31. de Meneses-Gaya C, Zuardi AW, Loureiro SR, et al. Alcohol Use Disorders Identification Test (AUDIT): An updated systematic review of psychometric properties. Psychol Neurosci 2009;2:83-97.

32. Carver CS. You want to measure coping but your protocol's too long: consider the brief COPE. Int J Behav Med 1997;4:92-100.

33. Derogatis LR, Melisaratos N. The Brief Symptom Inventory: an introductory report. Psychol Med 1983;13:595-605.

34. Schwab KA, Ivins B, Cramer G, et al. Screening for traumatic brain injury in troops returning from deployment in Afghanistan and Iraq: initial investigation of the usefulness of a short screening tool for traumatic brain injury. J Head Trauma Rehabil 2007;22:377-89.

35. Schwab KA, Baker G, Ivins B, et al. The Brief Traumatic Brain Injury Screen (BTBIS): investigating the validity of a self-report instrument for detecting traumatic brain injury (TBI) in troops returning from deployment in Afghanistan and Iraq. Neurology 2006;66:A235.

36. Van Dyke SA, Axelrod BN, Schutte C. Test-retest reliability of the traumatic brain injury screening instrument. Mil Med 2010;175:947-9.

37. Radloff LS. The CES-D Scale. Appl Psychol Meas 1977;1:385-401.

38. Worm-Smeitink M, Gielissen M, Bloot L, et al. The assessment of fatigue: psychometric qualities and norms for the Checklist individual strength. J Psychosom Res 2017;98:40-6.

39. Cook WW, Medley DM. Proposed hostility and Pharisaic-virtue scales for the MMPI. J Appl Psychol 1954;38:414-8.

40. Barefoot JC, Dodge KA, Peterson BL, et al. The Cook-Medley hostility scale: item content and ability to predict survival. Psychosom Med 1989;51:46-57.

41. King LA, King DW, Vogt DS, et al. Deployment Risk and Resilience Inventory: A collection of measures for studying deploymentrelated experiences of military personnel and veterans. Mil Psychol 2006;18:89-120.

42. Denollet J. DS14: standard assessment of negative affectivity, social inhibition, and Type D personality. Psychosom Med 2005;67:89-97.

43. Bremner JD, Bolus R, Mayer EA. Psychometric properties of the Early Trauma Inventory-Self Report. J Nerv Ment Dis 2007;195:211-8.

44. Currier JM, Holland JM, Drescher K, et al. Initial psychometric evaluation of the Moral Injury Questionnaire-Military version. Clin Psychol Psychother 2015;22:54-63.

45. Blais A, Thompson MM, McCreary DR. The development and validation of the Army Post-Deployment Reintegration Scale. Mil Psychol 2009;21:365-86. 
46. Holi MM, Sammallahti PR, Aalberg VA. A Finnish validation study of the SCL-90. Acta Psychiatr Scand 1998;97:42-6.

47. Schmitz N, Hartkamp N, Kiuse J, et al. The Symptom CheckList-90-R (SCL-90-R): a German validation study. Qual Life Res 2000;9:185-93.

48. Ware JE, Sherbourne CD. The MOS 36-item short-form health survey (SF-36). I. Conceptual framework and item selection. Med Care 1992;30:473-83.

49. Aaronson NK, Muller M, Cohen PD, et al. Translation, validation, and norming of the Dutch language version of the SF-36 Health Survey in community and chronic disease populations. J Clin Epidemiol 1998;51:1055-68.

50. Hakkaart-van Roijen L, Bouwmans CAM. Handleiding Short formHealth and Labour Questionnaire [Manual Short Form-Health and Labour Questionnaire]. Rotterdam, The Netherlands: Institute for Medical Technology Assessment, 2010

51. van Roijen L, Essink-Bot ML, Koopmanschap MA, et al. Labor and health status in economic evaluation of health care. The Health and Labor Questionnaire. Int J Technol Assess Health Care 1996;12:405-15.

52. van Sonderen E. Het meten van sociale steun met de Sociale Steun Lijst - Interacties (SSL-I) en Sociale Steun Lijst - Discrepanties (SSL-D): Een handleiding [Measuring social support with the Social Support List - Interaction (SSL-I) and Social Support List Discrepancies (SSL-D): A manual]. Groningen, The Netherlands: Research Institute SHARE, 2012.
53. Bridges KR, Sanderman R, van Sonderen E. An English language version of the social support list: preliminary reliability. Psychol Rep 2002;90:1055-8.

54. Spielberger CD. STAXI-2: State-Trait Anger Expression Inventory-2 - Professional manual. Odessa, FL: Psychological Assessment Resources, 1999.

55. Lievaart M, Franken IH, Hovens JE. Anger assessment in clinical and nonclinical populations: further validation of the state-trait anger expression inventory-2. J Clin Psychol 2016;72:263-78.

56. Cloninger CR, Svrakic DM, Przybeck TR. A psychobiological model of temperament and character. Arch Gen Psychiatry 1993;50:975-90.

57. Duijsens IJ, Spinhoven P. VTCl: Handleiding van de Nederlandse verkorteTemperament en Karakter vragenlijst [TCI-SF: Manual of the Dutch short form Temperament and Character Inventory]. Leiderdorp, The Netherlands: Datec, 2002.

58. Schaufeli WB, van Dierendonk D. Handleiding van de Utrechtse Burnout Schaal (UBOS) [Manual Utrecht Burnout Scale (UBOS)]. Utrecht, The Netherlands: Swets \& Zeitlinger, 2000.

59. Roelofs J, Verbraak M, Keijsers GPJ, et al. Psychometric properties of a Dutch version of the Maslach Burnout Inventory General Survey (MBI-DV) in individuals with and without clinical burnout. Stress Health 2005;21:17-25.

60. Mooren T, Schok M, Kleber RJ. De zin van ingrijpende gebeurtenissen: een vragenlijst over betekenisgeving na oorlogs- en geweldservaringen. Psychologie en Gezondheid 2009;37:101-10. 